\title{
Cellulose Acetate as Solid Phase in ELISA for Plague
}

\author{
AD Barbosa, FSM de Barros, EQ Callou, AMP Almeida/*, AM Araujo**, \\ WM Azevedo, LB Carvalho Jr/ ${ }^{+}$
}

\begin{abstract}
Laboratório de Imunopatologia Keizo Asami and Departamento de Química Fundamental, Universidade Federal de Pernambuco, Cidade Universitária, 50670-420 Recife, PE, Brasil *Fundação de Hematologia e Hemoterapia de Pernambuco, Recife, PE, Brasil **Centro de Pesquisas Aggeu Magalhães-Fiocruz, Recife, PE, Brasil

Antigen from Yersinia pestis was adsorbed on cellulose acetate discs $(0.5 \mathrm{~cm}$ of diameter $)$ which were obtained from dialysis membrane by using a paper punch. ELISA for human plague diagnosis was carried out employing this matrix and was capable to detect amount of $1.3 \mu \mathrm{g}$ of antigen, 3,200 times diluted positive serum using human anti-IgG conjugate diluted 1:4,000. No relevant antigen lixiviation from the cellulose acetate was observed even after washing the discs 15 times. The discs were impregnated by the coloured products from the ELISA development allowing its use in dot-ELISA. Furthermore, cellulose acetate showed a better performance than the conventional PVC plates.
\end{abstract}

Key words: cellulose acetate - Yersinia pestis - ELISA

In our laboratories, modified polymers have been proposed as matrices for antigen immobilization such as Dacron; ferromagnetic Dacron (Carneiro Leão et al. 1991) and PVA-glutaraldehyde (Araujo et al. 1996). Here, cellulose acetate is proposed as an alternative support for antigen immobilization.

Dialysis membrane of cellulose acetate (Sigma) was cut in discs by using a paper puncher $(0.5 \mathrm{~cm}$ of diameter). The discs were then introduced into flat bottomed tissue culture microplates covered with $100 \mu \mathrm{l}$ of F1 antigen (Baker et al. 1952) containing $130 \mathrm{ng}$ of protein, obtained from Yersinia pestis, and left at $4^{\circ} \mathrm{C}$ overnight. These treated discs were washed twice with $0.1 \mathrm{M}$ sodium carbonate buffer (SCB), pH 9.2, added by $0.05 \%$ Tween 20 (Labsynth); blocked with 3\% w/v skimmed milk (Molico, Nestlé), prepared in SCB, for $2 \mathrm{~h}$ at $4^{\circ} \mathrm{C}$ and washed with SCB/Tween once.

Diluted human serum (100 $\mu$ of a 1:3,200 dilution in SCB) was incubated with the antigen-disc into clean microplates at $37^{\circ} \mathrm{C}$ for $60 \mathrm{~min}$. After washing the antigen-antibody-disc complex five times with SCB/Tween, $100 \mu$ l of goat anti-human IgG (Sigma) conjugated to peroxidase diluted from

\footnotetext{
${ }^{+}$Corresponding author. Fax: $+55-81-271.8485$.

E-mail: lbcj@abayar.econnect.com.br

Received 22 June 1999

Accepted 22 November 1999
}

$1: 2,000$ to $1: 32,000$ times in $3 \% \mathrm{w} / \mathrm{v}$ skimmed milk were added and incubated at $37^{\circ} \mathrm{C}$ for $60 \mathrm{~min}$. Afterwards, five washings with $\mathrm{CBB} /$ Tween were carried out. Then, the substrate solution $(100 \mu \mathrm{l})$, composed of $0.325 \% \mathrm{w} / \mathrm{v}$ orthophenylenediamine dihydrocloride (OPD-Sigma) and $0.085 \% \mathrm{H}_{2} \mathrm{O}_{2}$ prepared in $0.3 \mathrm{M}$ Tris-citrate buffer, $\mathrm{pH} 6.0$, was added. After incubation at room temperature $\left(28^{\circ} \mathrm{C}\right)$ for $15 \mathrm{~min}$, in the dark, the reaction was stopped with $2.5 \mathrm{M} \mathrm{H}_{2} \mathrm{SO}_{4}(25 \mu \mathrm{l})$ and the plates read in ELISA reader (Bio-rad) at $492 \mathrm{~nm}$. This procedure was carried out in duplicates as well as all those throughout this work. The results are displayed in Fig. 1. The highest ratio (7.97) between positive and negative optical density (OD) was found at the dilution of 1:4,000 which was selected as the best for the ELISA development.

ELISA was carried out as above except that antigen amount and serum dilution ranged from $78 \mathrm{ng}$ to $20 \mu \mathrm{g} / \mathrm{well}$ and $1: 200$ to $1: 25,600$, respectively. Goat anti-human IgG conjugate was diluted 1:4,000 as above estimated. These titrations are presented in Fig. 2. According to this figure the optimal antigen and serum dilutions were determined to be $1: 320(1.3 \mu \mathrm{g} / \mathrm{ml})$ and $1: 3,200$, respectively. Hyperbolic curves were almost described since OD decay was observed above a certain antigen concentration value. This can be attributed to no antigen-antibody complex formation due to steric hindrance .

Antigen-discs were washed from twice to 15 times with SCB/Tween previously to ELISA and the results showed OD values for control, nega- 


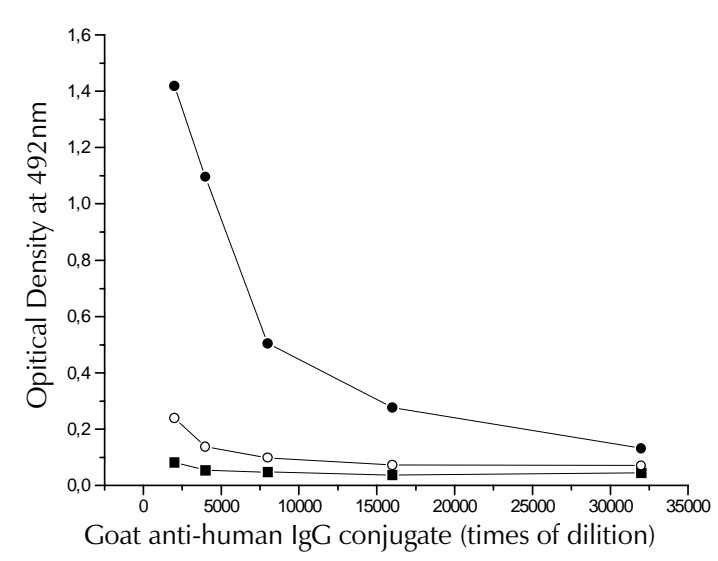

Fig. 1: titration of goat anti-human IgG conjugate. Experimental conditions: antigen-disc (1.3 $\mu \mathrm{g} / \mathrm{disc})$; blocked with $3 \% \mathrm{w} / \mathrm{v}$ skimmed milk prepared in sodium carbonate buffer (SCB); positive (O) and negative $(\mathrm{O})$ human serum (diluted 1:3,200); SCB as control (ם); goat anti-human IgG conjugated to peroxidase diluted as indicated and the reaction read at $492 \mathrm{~nm}$.

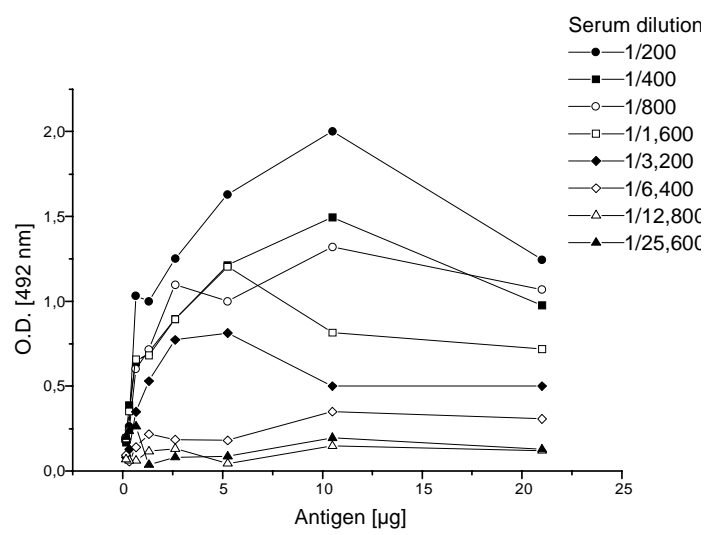

Fig. 2: antigen and serum titration using ELISA based on cellulose acetate discs. Experimental conditions: antigen-disc (blocked with $3 \% \mathrm{w} / \mathrm{v}$ skimmed milk prepared in sodium carbonate buffer) concentrations and human serum dilutions as indicated; goat anti-SCB human IgG conjugated to peroxidase diluted 1:4,000 and the reaction read at $492 \mathrm{~nm}$.

tive and positive serums equal to $0.035 \pm 0.008$; $0.033 \pm 0.007$ and $0.310 \pm 0.038$, respectively. No relevant antigen lixiviation from the cellulose acetate was observed provided that the OD decreased only $12.3 \%$ after 15 washings using positive se- rum, whereas negligible OD variation was detected for the negative serum and control.

Comparison between a commercially available ELISA microplate (Maxsorbent) with the cellulose acetate discs was carried out under the same experimental conditions (Fig. 3). Cellulose acetate, the present solid-phase, showed a better performance than the conventional PVC plates.

Finally, it is worthwhile to register that the cellulose acetate discs were impregnated by the coloured products from the ELISA development (reduced OPD by the peroxidase catalysis). Thus,

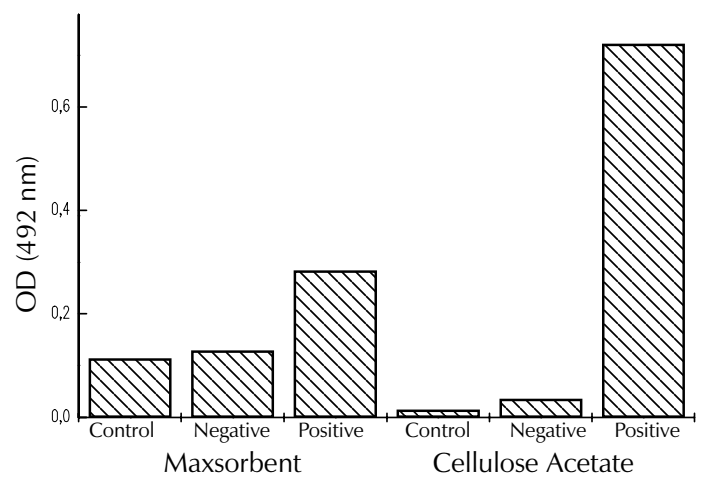

Fig. 3: comparison of ELISA using PVC microplates (Maxsorbent) or cellulose acetate discs.

high OD for the ELISA will give intensive yellow colour disc. This can be easily seen at least for two hours. Therefore, dot-ELISA can also be performed by using these discs obtained from cellulose acetate membrane dialysis.

\section{REFERENCES}

Araujo AM, Petribú ATS, Barbosa GHTS, Diniz JRP, Almeida AMP, Azevedo WM, Malagueño E, Carvalho Jr LB 1996. The use of polyvinyl alcohol glutaraldehyde as solid-phase in ELISA for plague. Mem Inst Oswaldo Cruz 91: 195-198.

Baker EE, Sommer H, Foster L E, Meyer KF 1952. Studies on immunization against plague. I. The isolation and characterization of the soluble antigen of Pasteurella pestis. J Immunol 68: 131-40.

Carneiro Leão, AMA, Oliveira EA, Carvalho Jr LB 1991. Immobilization of protein on ferromagnetic dacron. Applied Biochem Biotechn 31: 53-58. 